Dept. of Biotechnology,

Animal Health Research Institute, Dokki, Egypt.

\title{
APPLICATION OF PCR TECHNIQUE FOR ANIMAL SPECIES IDENTIFICATION OF RAW AND HEAT- TREATED MEAT MIXTURES
}

(With One Table and 4 Figures)

\author{
By
}

M.A. AGGOUR; NASHWA M. HELMY;

SUZAN M.A. ABU-ZEID*; ENSHRAH K.I. MIRA*

\section{and K.A. MOHRAN*}

* Dept. of Food Hygiene, Animal Health Research Institute, Dokki, Egypt.

(Received at 23/10/2010)

\section{تطبيق اختبار إنزيم البلمرة المتسلسل للتعرف على فصائل الحيوانات فى خليط من اللحوم الخام والمعاملة حراريا لإعليا فيل

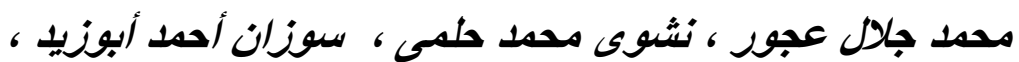 انشراح خليل مبيرة ، خالد عبل الدكيم مهران}

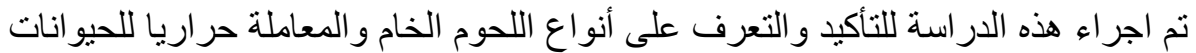

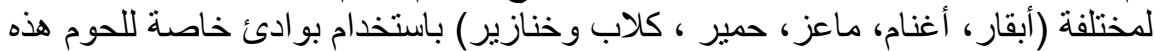

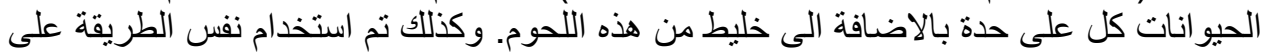

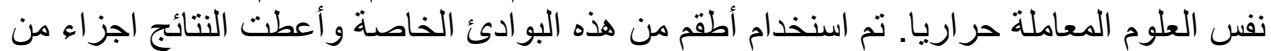

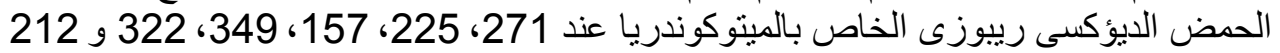

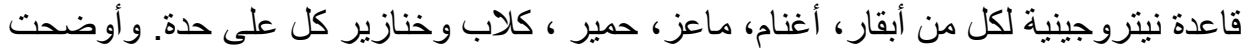

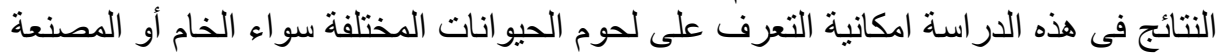
(المعاملة حراريا) باستخدام اختبار تفاعل انزيم البلمرة المنسلسل كطريقة سهلة وسريعة ودقيقة.

\section{SUMMARY}

The present study was designed to investigate PCR methods for identification and authentication for different kinds of meat based on species specific PCR. Cattle, sheep, goat, donkey, dog and pig meat were used separately and in meat mixture. The effect of thermal treatment of the sample on PCR technique's ability to identify species was studied through the analysis of microwaved meat mixture. Six sets of species specific primers were used to amplify mitochondrial DNA (mt DNA) specific for cattle, sheep, goat, donkey, dog and pig independently. The PCR 
conditions were optimized on meat of each species separately. The PCR produced a single band of expected size at 271, 225, 157, 439, 322 and 212 $\mathrm{bp}$ in the above mentioned animal meat respectively. The results obtained in this study demonstrate the suitability of PCR analysis to identify meat of different animal species with the use of species specific primers. Moreover, the technique could be used to identify the species included in animal feed or in meat products submitted to intense heat treatment as it is rapid, reliable, accurate and easy to perform.

Key words: PCR, meat, meat mixtures, animal species identification, heat-treated meat mixtures.

\section{INTRODUCTION}

Traditionally, animal species identification has been applied mainly for detection of commercial fraud, which involves substitution of an animal species of high commercial value, such as beef, by other species of lower commercial value. It is also a valuable tool for the assessment of risk associated with introduction of animal material that might be harmful to human or animal health such as Bovine spongiform encephalopathy (BSE) (Corona et al., 2007).

The detection of meat species is needed to be performed for other reasons, which includes religious and conservation regulations etc. In India, it becomes especially important due to socio-religious issues associated with the preference. There is religious taboo on the consumption of pork in Muslims and cattle meat in Hindus. There is a ban on the slaughter of cows and bullocks in many states of India. Inspite of ban, cows and bullocks are occasionally slaughtered. Frequently, meat samples are brought to laboratories for identification and confirmation of meat species. Ultimately, the species identification from mixed meat is very critical. However, it is not always possible to differentiate the species by currently available laboratory methods (Rajni, 2007)

The conventionally available methods for species identification from mixed meat include various forms of electrophoresis and use of immune sera in agar gel diffusion. Some of such methods of animal tissue identification are agar gel diffusion, passive haemagglutination, immunoelectrophoresis, counter immunoelectrophoresis, enzyme-linked immunosorbent assay etc. However, the greatest disadvantage of immunological methods for species identification is that the available antisera show cross-reactions. Secondly during cooking the solubility properties and antigens competence of the proteins are altered 
considerably. The use of antisera to thermostable antigens has proved to be superior in identification of cooked meat. However, use of such antigens and antisera against them are only partially successful in identification of meats of closely related species of animals like cattle and buffalo from sheep and goats (Bhilegaonkar et al., 1989). In recent past, DNA as a source of information has been used for speciation of meats. DNA based technology for such purpose has several advantages. DNA is more thermostable than many proteins and thus nucleic acids are less liable to be disrupted by processing of foods. It is present in majority of the cells of an organism and therefore, identical information can be obtained from any appropriate sample from the same source, regardless of the tissue of origin. DNA can potentially provide more information than proteins (Corona et al., 2007).

Two major approaches to identify species of meats by DNA techniques are DNA hybridization and PCR based methods. DNA hybridization was the first genetic approach for determination of species identity. In this method, labeled DNA probes were hybridized to samples of genomic DNA covalently attached to nylon membranes in a slot or dot blot form (Baur et al., 1989). It was observed that the probes comprising labeled total genomic DNA from a given species would hybridize to DNA from the same species with little cross reactivity. The technique of DNA hybridization has been successfully applied for identification and differentiation of meats of chicken and pork from cooked meats and commercial products (Ebbehoj and Thomsen, 1991). However, meats of closely related species of animals, like sheep and goats showed cross reactivity by this method. In spite of several advantages of DNA hybridization methods for identification and differentiation of meats of different species of animals, these are complicated and generally inadequate.

PCR is a promising approach to species identification. This method is easy, fast and more sensitive. A number of strategies has been employed in PCR including use of repetitive sequences (Calvo et al., 2001), multigene family (Fairbrother et al., 1998) and use of mitochondrial gene (Matsunaga et al., 1999) for species identification.

PCR analysis of species-specific mt DNA sequence is the most common method currently being used for species identification (Parodi et al., 2002). Detection method based on mt DNA can improve the sensitivity further because each cell has around 104 copies of mt DNA as against just one genomic DNA. Since mt DNA expressed in different species or genera have their evolution specificities, we can identify 
individual species by studying mt DNA (Ilhak and Arslan, 2007). Therefore, mt DNA is efficiently used to detect species -specific DNA.

Methods based on DNA amplification are preferred, as they are less affected by industrial processing (Pascoal et al., 2005). Generally, mitochondrial DNA (mtDNA) based PCR methods have given good results in analysis of samples submitted to temperature and pressure treatments, in which DNA has been partly degraded (Bottero et al., 2003; Rodríguez et al., 2004).

The present study was designed to investigate PCR methods for identification and authentication for different kinds of processed cattle, sheep, goat, donkey, dog and pig meat based on species specific PCR to identified processed cattle, sheep, goat, donkey, dog and pig meat separately and in meat mixture.

\section{MATERIALS and METHODS}

Meat samples: Meat samples of cattle, sheep, goat, donkey, dog and pig were purchased and collected from Cairo City, Egypt. Meat was wrapped in aluminium foil and cooked in microwave oven at $100{ }^{\circ} \mathrm{C}$ for 30 minutes (Shally, 2004). DNA was extracted from each meat sample and stored at $-20 \pm 1{ }^{\circ} \mathrm{C}$ until analyzed.

Test meat mixtures: Each meat samples of cattle, sheep and goat were mixed with meat samples of pig, dog and monkey separately. Following mixing, a $2 \mathrm{gm}$. portion of each sample was taken separately from each test mixture. DNA was extracted from each test meat sample and used for PCR analysis.

DNA Extraction: DNA was extracted from each meat sample and each test meat sample by the DNeasy protocol provided with animal and Fungi DNA Preparation Kit (Jena Bioscience Cat. No. PP-208S). Extraction was performed on 5-10 $\mathrm{mg}$ of fresh or frozen meat sample on a $1.5 \mathrm{ml}$ microtube. containing $300 \mu \mathrm{l}$ Cell Lysis Solution and $1.5 \mu \mathrm{l}$ Proteinase $\mathrm{K}(20 \mathrm{mg} / \mathrm{ml})$. The mixture was incubated at $55^{\circ} \mathrm{C}$ overnight or until tissue has dissolved. At the second day, $100 \mu$ of Protein Precipitation Solution was added to the cell lysate and mix well by vortexing. Then centrifugation at $15,000 \mathrm{~g}$ for $3 \mathrm{~min}$. (The precipitated protein will be a tight pellet). DNA was precipitated from the supernatant by isopropanol alcohol $99 \%$ and washed by ethanol alcohol $80 \%$. After the DNA was pelleted by centrifugation and air dried, the DNA was dissolved in $50 \mathrm{ul}$ hydration solution containing $1.5 \mathrm{ul} \mathrm{RNase} \mathrm{A}$ at $37{ }^{\circ} \mathrm{C}$ for $30 \mathrm{~min}$. then at $65{ }^{\circ} \mathrm{C}$ for $60 \mathrm{~min}$. (Mohamed et al., 2007). 


\section{Polymerase chain reaction}

Oligonucleotide primers: PCR primers for the amplification of bovine, sheep, goat, horse and pig meat were designed as described by Lahiff et al. (2001) and Matsunaga et al. (1999). Species specific primers for the detection of dog were designed as described by Ilhak and Arslan, 2007. The sequence of the primers were illustrated in Table (1).

Table 1: The sequences of six set ofspecies specific oligonucleotide primers used for the detection of cattle, sheep, goat, donkey, dog and pig meats.

\begin{tabular}{|c|c|c|}
\hline & Sequences 5-3 & $\begin{array}{c}\text { Amplified } \\
\text { products }\end{array}$ \\
\hline \multirow{2}{*}{ Bovine } & 5'-GCCATATACTCTCCTTGGTGACA- 3 & \multirow{2}{*}{$271 \mathrm{bp}$} \\
\hline & 5'- GTAGGCTTGGGAATAGTACGA- 3' & \\
\hline \multirow{2}{*}{ Sheep } & 5'- TTAAAGACTGAGAGCATGATA- 3' & \multirow{2}{*}{$225 \mathrm{bp}$} \\
\hline & 5'-ATGAAAGAGGCAAATAGATTTTCG- 3' & \\
\hline \multirow{2}{*}{ Goat } & 5'- GACCTCCCAGCTCCATCAAACATCTCATCTTGATGAAA- 3' & \multirow{2}{*}{$157 \mathrm{bp}$} \\
\hline & 5'- CTCGACAAATGTGAGTTACAGAGGGA- 3' & \\
\hline \multirow{2}{*}{ equine } & 5'- GACCTCCCAGCTCCATCAAACATCTCATCTTGATGAAA- 3' & \multirow{2}{*}{$439 \mathrm{bp}$} \\
\hline & 5'- CTCAGATTCACTCGACGAGGGTAGTA- 3' & \\
\hline \multirow{2}{*}{ Porcine } & 5'- GCC TAA ATC TCC CCT CAA TGG TA- ${ }^{\prime}$ & \multirow{2}{*}{212 bp } \\
\hline & 5'-ATGAAA GAG GCA AAT AGA TTT TCG-3, & \\
\hline \multirow{3}{*}{ Dog } & 5'- GAT GTG ATC CGA GAA GGC ACA- 3' & \\
\hline & ร - UА & \multirow[t]{2}{*}{$322 \mathrm{bp}$} \\
\hline & 5'- TTG TAA TGA ATA AGG CTT GAA G- 3' & \\
\hline
\end{tabular}

DNA amplification: DNA amplification was done in 25 ul reaction volume containing $2.5 \mathrm{ul}$ of $10 \mathrm{X}$ reaction buffer $(65 \mathrm{mM}$ Tris- $\mathrm{Hcl}, \mathrm{PH} 8.8$ at $25^{\circ} \mathrm{C}, 16 \mathrm{mM}$ ammonium sulphate, $200 \mathrm{ug}$ of gelatin per $\left.\mathrm{ml}\right), 200 \mathrm{uM}$ of each of four deoxyribonucleotide triphosphates, $10 \mathrm{pM}$ of each oligonucleotide primer, $2 \mathrm{mM}$ magnesium chloride, $1 \mathrm{U}$ of Taq DNA 
polymerase and $50 \mathrm{ng}$ of template DNA (Johannes et al., 2001). PCR was carried out in a gene cycler (Perken Elmer model 6900).

The optimized cycle program for PCR of denaturation, annealing and extension temperatures was as follow: initial denaturation of $5 \mathrm{~min}$ at $94^{\circ} \mathrm{C} ; 30$ cycles of 1 minute at $94^{\circ} \mathrm{C}, 1$ minute at $50^{\circ} \mathrm{C}$ and $2 \mathrm{~min}$. at $72^{\circ} \mathrm{C}$; and final extension step at $72^{\circ} \mathrm{C}$ for 5 min (Johannes et al., 2001). After amplification a $5 \mathrm{ul}$ of the reaction product was mixed with $1 \mathrm{ul}$ of $6 \mathrm{X}$ gel loading buffer and subjected to electrophoresis on $1.5 \%$ agarose gel at $100 \mathrm{~V}$ for $30 \mathrm{~min}$. Gel were stained with ethiduim bromide and photographed on UV transilluminator (Ilhak and Arslan, 2007). Samples were considered positive when a single band of DNA of PCR amplification product size in cattle's, sheep's, goat's, donkey's, pig's and dog's meat were at 271, 225, 157, 439, 212 and 322 bp, respectively, were evident in the ethidium bromide stained gels compared with the molecular size marker 100-bp DNA ladder (Jena Bioscience Cat. No. M-214). The gels were then photographed using a Polaroid Camera.

\section{RESULTS}

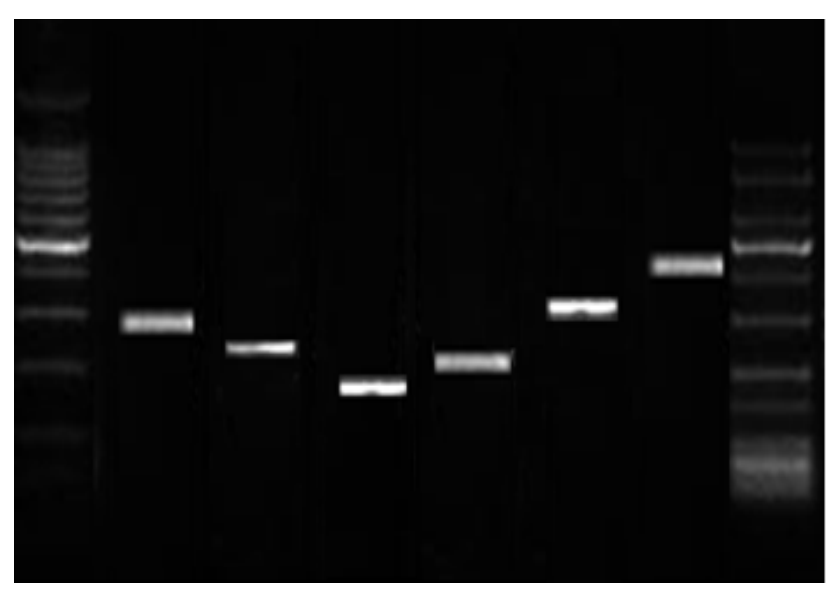

Fig. 1: Ethidium bromide stained agarose gel 1.5\% electrophoresis showed amplified fragment of mitochondrial DNA with species specific primers Where, lane M1: 100 bp DNA marker (100, 200, 300, 400, $500 \mathrm{bp}$ and etc.), lane 1 - 6: meat samples of cattle, sheep, goat ,pig, dog and donkey showed 271,225, 157,212, 322 and 439 bp respectively. Lane M2: 50 bp ladder ( 50, 75, 100, 150, 200, 300, 400 and etc.) 


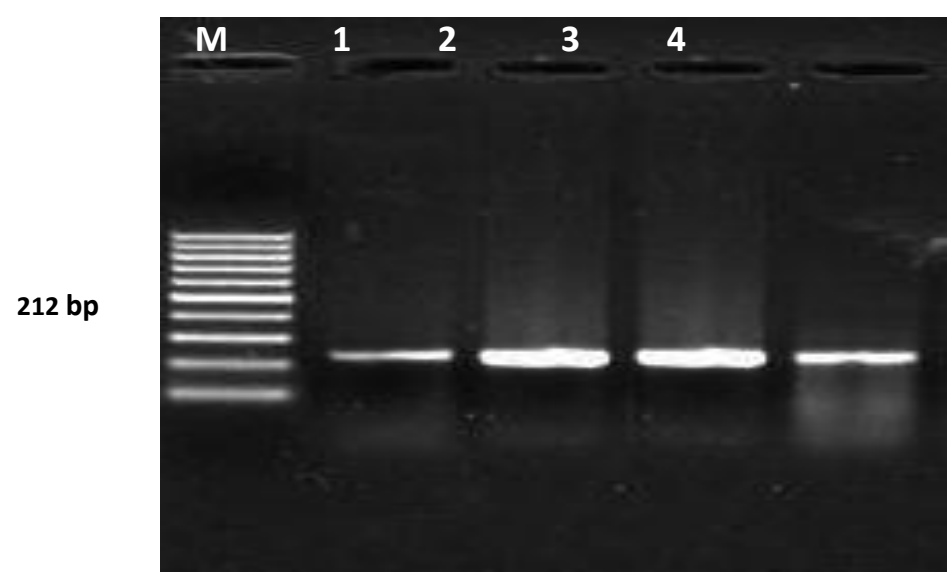

Fig. 2: Ethidium bromide stained agarose gel $1.5 \%$ electrophoresis showed amplified fragment of $212 \mathrm{bp}$ resulting from amplification of mitochondrial DNA generated by primers specific for pig species. Where, lane M: 100 bp DNA marker (100, 200, 300, 400, 500 bp and etc.), lane 1: pig meat as positive control, lane 2- 5: meat samples of cattle, sheep and goat mixed with meat samples of pig separately respectively.

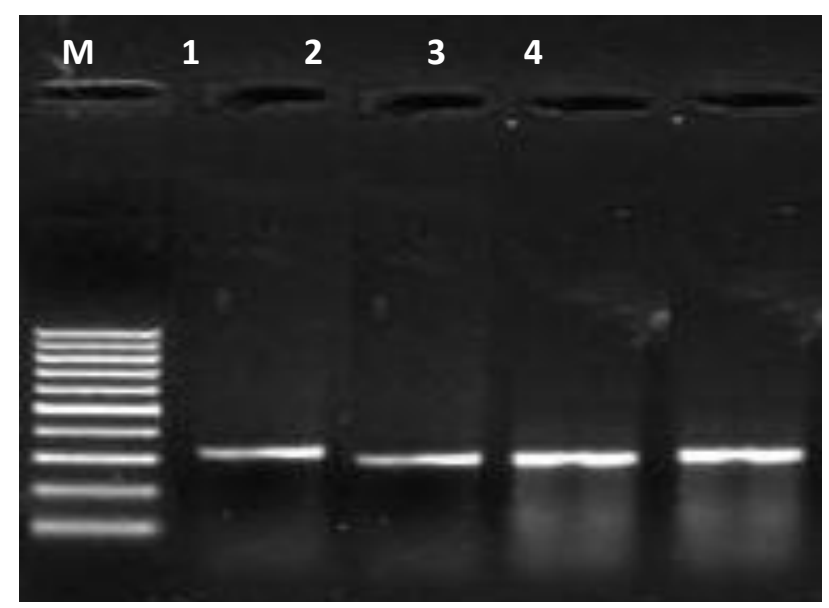

Fig. 3: Ethidium bromide stained agarose gel $1.5 \%$ electrophoresis showed amplified fragment of 322 bp resulting from amplification of mitochondrial DNA generated by primers specific for dog species. Where, lane M: 100 bp DNA marker (100, 200, 300, 400, 500 bp and etc.), lane 1: dog meat as positive control, lane 2-4: meat samples of cattle, sheepand goat mixed with meat samples of dog separately respectively respectively. 


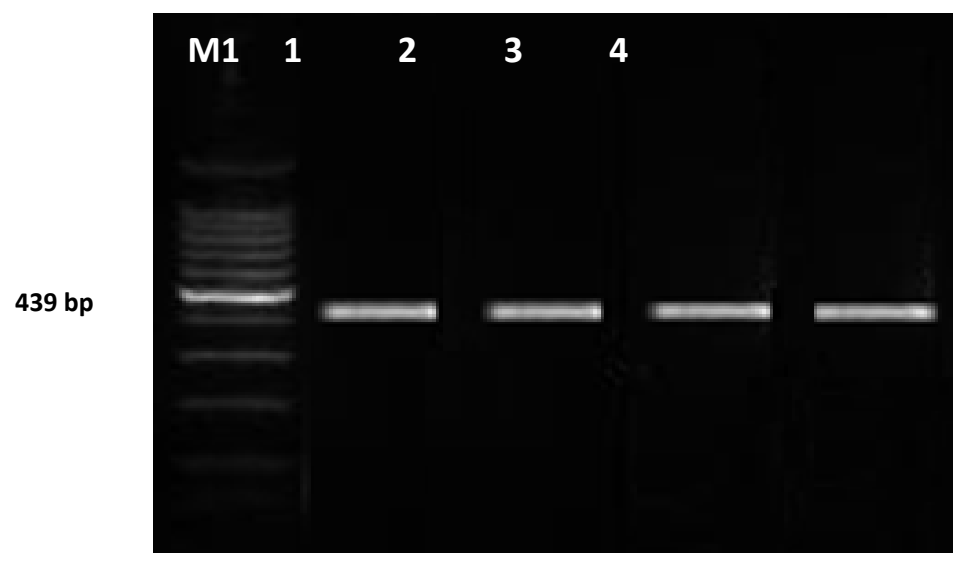

Fig. 4: Ethidium bromide stained agarose gel $1.5 \%$ electrophoresis showed amplified fragment of $439 \mathrm{bp}$ resulting from amplification of mitochondrial DNA generated by primers specific for horse species. Where, lane M1: 100 bp DNA marker (100, 200, 300, 400, 500 bp and etc.), lane 1:donkey meat as positive control, lane 2- 4: meat samples of cattle, sheep and goat mixed with meat samples of donkey separately respectively.

\section{DISCUSSION}

Nucleic acids present in food are of no nutritional value but are characteristic for the various biological components in complex products. Analysis of specific nucleic acids in food allows the determination of the presence or absence of certain constituents in complex products or the identification of specific characteristics of single food components. As DNA is a rather stable molecule, processed food is generally analyzed using DNA-based method. Because of the high sensitivity, the specificity and rapidity of DNA-based methods, the polymerase chain reaction (PCR) is the method of choice which used in this study.

Six set of species-specific primers were used to amplify mitochondrial DNA (mt DNA) specific for cattle, sheep, goat, horse, dog and pig independently. The PCR conditions were optimized on meat of each species separately. The PCR produced a single band of expected size at $271,225,157,439,322$ and $212 \mathrm{bp}$ in above mentioned animals meat respectively, (Fig. 1). This results confirming that the primers used in this study are specific for its species and did not show any cross-reactivity with others. 
By application of PCR by using pig specific primers on the test meat mixture, meat samples of cattle, sheep and goat which mixed with meat samples of pig, give a single band at 212 bp (Fig. 2), while, by application of PCR by using dog specific primers on the test meat mixture, meat samples of cattle, sheep, and goat which mixed with meat samples of dog give a single band at 322 bp. (Fig. 3). Also, by application of PCR by using horse specific primers on the test meat mixture, meat samples of cattle, sheep, and goat which mixed with meat samples of donkey give a single band at 439 bp. (Fig. 4). This results supported the findings published by Ilhak and Arslan (2007); Meyer et al. (1994, 1995); Hopwood et al. (1999) and Partis et al. (2000), who reported that PCR could be used for identification of meat mixes at $0.5 \%$ levels.

PCR analysis of species-specific mtDNA sequences is the most common method currently used for species identification (Cann et al., 1987; Parodi et al., 2002). Detection method based on mtDNA can improve the sensitivity further because each cell has only a set of genomic DNA in the nucleus, but bearing several copies of mtDNA. There are approximate 1000 mitochondria in a cell and 10 copies of mtDNA per mitochondrion, much copies of mtDNA are available per cell and just one copy for genomic DNA. Therefore, mtDNA efficiently to detect speciesspecific DNA than genomic DNA.

Moreover, Olivier et al. (2009) reported that the high forensic value of PCR results is based on the research of specific targets in DNA sequences present in each cell of an organism and conserved at a suitable taxonomic level, commonly at species or groups of animals levels like ruminants or mammals. The detection of multi-copy targets instead of single copy onessuch as mitochondrial DNA is of major interest as it can be present up to hundred of copies per cell depending on the type of tissue.

The effect of thermal treatment of the samples on PCR technique's ability to identify species was studied through the analysis of microwaved meat mixture.

Many a times species identification of cooked meat is warranted. The processing technology (salting, drying, smoking, and cooking) applied during the manufacture of meat products may affect to different extents to the integrity of the extractable DNA. Heat treatments are those steps, which mainly affect the quality of DNA causing its degradation into small size fragments (Dias Neto et al., 1994; Martinez and Man., 1998). For this reason, meat samples were cooked in the present study at $100{ }^{\circ} \mathrm{C}$ in microwave oven for 30 minutes to simulate cooking. Proper cooking was evident from discolored meat. The high molecular weight DNA could be extracted in sufficient amounts. These results demonstrate the applicability 
of DNA techniques for these kinds of samples as previously reported (Koh et al., 1998; Martinez and Man, 1998; Dias Neto et al., 1994; Calvo et al., 2001).

\section{CONCLUSION}

The results obtained in this study demonesterate the suitability of PCR analysis to identify meat of different animal species with the use of species - specific primers. Moreover, the technique could be used to identify the species included in animal feed or in meat products submitted to intense heat treatment as it is rapid reliable, accurate and easy to perform. This technique could prove useful for inspection programs intended to assess the species identity of meat products.

\section{Acknowledgement}

Many thanks to prof. Dr. Hosni El- sawah, Prof. of Food Hygiene, Animal Health Research Institute for his kind help, valuable advise and encouragement throughout this work.

\section{REFERENCES}

Baur, C.; Teifel, G.J. and Liebhardt, E. (1989): Species identification by fragmented DNA. Beitr Gerichtl Med. 47: 165-170.

Bhilegaonkar, K.; Sherikar, A.; Khot, J. and Karkare, U. (1989): Studies on characterisation of thermostable antigens of adrenals and muscle tissues of meat animals. Journal of the Science of Food and Agriculture 51 (4): 545-553.

Bottero, M.T.; Civera, T.; Nucera, D.; Rosati, S.; Sacchi, P. and Turi, R.M. (2003): A multiplex polymerase chain reaction for the identification of cows', goats' and sheep's milk in dairy products. J. Int. Dairy 13: 77-282.

Calvo, J.H.; Zaragoza, P. and Osta, R. (2001): Technical note: A quick and more sensitive method to identify pork in processed and unprocessed food by PCR amplification of a new specific DNA fragment. J. Anim. Sci. 8: 2108-2112.

Cann, R.L.; Stoncking, M. and Wilson, A.C. (1987): Mitochondrial DNA and human evolution. Nature 325: 31-36.

Corona, B.; Lleonard, R.; Carpio, Y.; Uffo, O. and Martínez, S. (2007): Short communication. PCR detection of DNA of bovine, ovinecaprine and porcine origin in feed as part of a bovinespongiform 
encephalopathy control program. Spanish Journal of Agricultural Research , 5(3): 312-317.

Dias Neto, E.; Caballero, O.L.; Vidigal, T.; Pena, S. and Simpson, A. (1994): Producing randomly amplified polymorphic DNAs from degraded DNA. In workshop of Genomic Fingerprinting. 20: 9495 Madrid, Spain: Instituto Juan March de Estudios e Investigaciones.

Ebbehoj, K.F. and Thomsen, P.D. (1991): Species differentiation of heated meat products by DNA hybridization. Meat Sci. 30(3): 221-234.

Fairbrother, K.S.; Hopwood, A.J.; Lockley, A.K. and Bardsley, R.G. (1998): Meat speciation by restriction fragment length polymorphisms analysis using $\alpha$-Actin cDNA probe. Meat Sci. 50: 105-114.

Hopwood, A.J.; Fairbrother, K.S.; Lockley, A.K. and Bardsley, R.G. (1999): An actin gene-related polymerase chain reaction test for identification of chicken in meat mixtures. Meat Sci. 53(4): 227-231.

Ilhak, O.I. and Arslan, A. (2007): Identification of meat species by polymerase chain reaction (PCR) technique. Turk. J. Vet. Anim. Sci. 31(3): 159-163.

Johannes, A.L.; Jacob, B.B. and Frederik, W.J. (2001): On the origin of meat-DNA techniques for species identification in meat products. Veterinary sciences tomorrow, online current awareness journal.

Koh, M.C.; Lim, C.H.; Chua, S.B.; Chew, S.T. and Phang, S.T.W. (1998): Random amplified DNA fingerprints for identification of red meat animal species. Meat. Sci. 48: 275-285.

Lahiff, S.; Glennon, M.; O'Brien, L.; Lyng, J.; Smith, T.; Maher, M. and Shilton, N. (2001): Species-specific PCR for the identification of bovine, porcine, and chicken species in meat and bone meal (MBM). Mol. Cell. Probes., 15: 27-35.

Martinez, I. and Man, Y. (1998): Species identification in meat products by RAPD analysis. Food Res. Int. 31(6-7): 459-466.

Matsunaga, T.; Chikuni, T.; Tanabe, R.; Muroya, S.; Shibata, K.; Yamada, J. and Shimmura, Y. (1999): A quick and simple method for the identification of meat species and meat products by PCR assay. Meat Sci. 51(2): 143-148.

Meyer, R.; Candrian, U. and Luthy, J. (1994): Detection of pork in heated meat products by the polymerase chain reaction. J. AOAC Int., 77: 617-622. 
Meyer, R.; H.felein, C.; Luthy, J. and Candrian, U. (1995): Polymerase chain reaction-restriction fragment length polymorphism analysis: a simple method for species identification in food. J AOAC Int., 78: $1542-1551$.

Mohamed, M.M.A.; Abdel-Rahman, S.M. and Amr, A.E. (2007): Application of Species-Specific Polymerase Chain Reaction and Cytocrome b Gene for Different Meat Species Authentication. Biotechnology, 6 (3): 426-430.

Olivier, F.; Pascal, V.; Ana, B.; Christoph von, H.; Vincent, B. and Gilbert, B. (2009): Methods of detection, species identification and quantification of processed animal proteins in feedingstuffs .Biotechnol. Agron. Soc. Environ. 13(S): 59-70.

Parodi, B.; Aresu, O.; Bini, D.; Lorenzini, R.; Schena, F.; Visconti, P.; Cesaro, M.; Ferrera, D.; Andreotti, V. and Ruzzon, T. (2002): Species identification and confirmation of human and animal cell lines: a PCR based approach. Biotechniques. 32: 433-440.

Partis, L.; Croan, D.; Guo, Z.; Clark, R.; Coldham, T. and Murby, J. (2000): Evaluation of a DNA fingerprinting method for determining the species origin of meats. Meat Sci., 54: 369-376.

Pascoal, A., Prado, M.; Calo, P.; Cepeda, A. and Velásquez, J.B. (2005): Detection of bovine DNA in raw and heat-processed foodstuffs, comercial foods and specific risk materials by a novel specific polymerase chain reaction method. Eur Food Res Technol 220: 444-450.

Rajni, K. (2007): Meat species identification by real time PCR. M Sc Thesis submitted to the Anand Agricultural University in the partial fulfilment of the requirements for the award of the degree.

Rodríguez, M.A.; García, T.; González, I.; Asensio, L.; Hernández, P.E. and Martín, R. (2004): PCR identification of beef, sheep, goat, and pork in raw and heattreated meat mixtures. J. Food Prot. 67(1): 172-177.

Shally, J. (2004): USE OF Cytochrome b gene variability in detecting meat species by multiplex pcr assay. M Sc Thesis submitted to the Anand Agricultural University in partial fulfilment of the requirements for the award of the degree. 